\title{
An assemblage of terrestrial isopods (Crustacea) in southern Brazil and its contribution to leaf litter processing 1
}

\author{
Aline F. Quadros ${ }^{2} \&$ Paula B. Araujo ${ }^{2}$ \\ 1 Contribution number 503 of the Departamento de Zoologia, Universidade Federal do Rio Grande do Sul. \\ 2 Programa de Pós-Graduação em Biologia Animal, Departamento de Zoologia, Universidade Federal do Rio Grande do Sul. \\ Avenida Bento Gonçalves 9500, Bloco IV, Prédio 43435, 91501-970 Porto Alegre, Rio Grande do Sul, Brasil. \\ E-mail: quadros.af@gmail.com; pbaraujo@portoweb.com.br.
}

\begin{abstract}
We present an assemblage of terrestrial isopods in Parque Estadual de Itapuã, southern Brazil, and estimate the contribution of two species to the leaf litter processing. After one year of sampling, we obtained 3748 individuals of six species and four eco-morphologic groups (in order of abundance): Balloniscus glaber Araujo \& Zardo, 1995, Atlantoscia floridana (van Name, 1940), Pseudodiploexochus tabularis (Giambiagi de Calabrese, 1939), Trichorhina sp., Alboscia itapuensis Araujo \& Quadros, 2005 and Novamundoniscus gracilis Lopes \& Araujo, 2003. Total monthly density corresponded to 368 individuals per square meter. The species $A$. itapuensis and $N$. gracilis represented less than $1 \%$ of total individuals. All the others showed aggregated distribution. Atlantoscia floridana and B. glaber had the highest proportion of individuals occurring together $(88 \%)$ and a significant species association. Their monthly biomass averaged $4.92 \mathrm{~kg} \mathrm{ha}^{-1}$ for B. glaber and $0.97 \mathrm{~kg} \mathrm{ha}^{-1}$ for A. floridana. Consumption rates, obtained in the lab (in $\mathrm{mg} \mathrm{mg}^{-1}$ day $^{-1}$ ) were $0.34 \pm 0.04$ and $0.70 \pm 0.18$ for $B$. glaber and $A$. floridana, respectively and assimilation efficiency was about $30 \%$. We estimated that both species together could process $860 \mathrm{~kg}$ leaves ha ${ }^{-1}$ year-1. $^{-1}$

KEY WORDS. Aggregation; eco-morphological groups; feeding rates; Isopoda; species association.
\end{abstract}

RESUMO. Uma assembléia de isópodos terrestres (Crustacea) no sul do Brasil e sua contribuição para o processamento da serapilheira. Neste estudo é descrita uma assembléia de isópodos terrestres no Parque Estadual de Itapuã e estimada a contribuição de duas espécies para o processamento da serapilheira. Após um ano, foram obtidos 3748 indivíduos, correspondendo a seis espécies de quatro grupos eco-morfológicos (em ordem de abundância): Balloniscus glaber Araujo \& Zardo, 1995, Atlantoscia floridana (van Name, 1940), Pseudodiploexochus tabularis (Giambiagi de Calabrese, 1939), Trichorhina sp., Alboscia itapuensis Araujo \& Quadros, 2005 e Novamundoniscus gracilis Lopes \& Araujo, 2003. A densidade mensal média correspondeu a 368 indivíduos por metro quadrado. As espécies $A$. itapuensis e $N$. gracilis representaram menos que $1 \%$ do total de indivíduos. As outras quatro espécies mostraram distribuição agregada. Atlantoscia floridana e B. glaber apresentaram $88 \%$ de indivíduos ocorrendo juntos. A biomassa mensal destas duas espécies foi de 4,92 $\mathrm{kg} \mathrm{ha}^{-1}$ (B. glaber) e 0,97 kg ha-1 (A. floridana). As taxas de consumo, em mg mg-1 dia ${ }^{-1}$ foram 0,34 $\pm 0,04$ (B. glaber) e 0,70 $\pm 0,18$ ( $A$. floridana). A eficiência de assimilação foi em torno de $30 \%$. Foi estimado que as duas espécies juntas são capazes de processar $860 \mathrm{~kg}$ folhas ha-1 ano-1.

PALAVRAS-CHAVE. Agregação; associação entre espécies; grupos eco-morfológicos; Isopoda; taxas de alimentação.

Terrestrial isopods (Crustacea, Oniscidea) are soil inhabitants widespread through a variety of habitats. Inventory and diversity studies have been conducted, and about 3,600 species are known (Schmalfuss 2003). Regarding oniscidean assemblages of coexisting species, some patterns can be drawn: they are usually composed by few species (up to 10) (Hassall \& Dangerfield 1989, Hornung \& Warburg 1996, Lymberakis et al. 2003, Zimmer 2003, Lopes et al. 2005), endemics and widely distributed (Judd \& Horwitz 2003, Lopes et al. 2005). The spatial distribution is not homogeneous (Hornung \& WARbURG 1995,
Judas \& Hauser 1998, Gongalsky et al. 2005), and may lead to strong species association (HASSALL \& DANGERFIELd 1989, ZimMER 2003) and there is a high fluctuation in density along the time (ZimMER 2003, LyMBERAKIs et al. 2003).

Syntopic oniscideans often show contrasting morphological and behavioral characteristics and belong to different eco-morphological groups (Schmalfuss 1984) and may avoid competition through species-specific utilization of resources, as for example, food (Zimmer 2003). The classification into ecomorphological groups, proposed by ScHMALfuss (1984), takes into

Revista Brasileira de Zoologia 25 (1): 58-66, March, 2008 
account their anti-predatory strategies, microhabitat use and body morphology/size, grouping the isopods in "runners', "clingers", "rollers", "creepers", "spiny forms" and "non-conformists".

Although still poorly studied, terrestrial isopods play an important ecological role in the soil, as members of the detritivore community. Especially in forests, detritivory is of great importance, as the litter layer provides the major source of decomposable organic matter which supplies the forest growth (Weвb 1977, FöRSTER et al. 2006). Detritivorous macroarthropods as isopods, diplopods and termites participate mainly in the processing of litter, by the mechanical breakdown and comminuting of the leaves (Wевв 1977), and are known to be responsible for the processing of up to $40 \%$ of the annual leaf fall is some environments (Матsumoto \& Aве 1979, Dangerfield \& Milner 1996, David \& Gillon 2002). As they generally have a low efficiency of assimilation, most of the ingested leaf litter returns to the soil as feces, which are chemically and physically different from the original vegetal material (Hassall \& Rushton 1982, Scheu \& Wolters 1991, Zimmer 2002). The feces are more suitable to microbial colonization and constitute a source of food for other soil organisms (SCHEU \& Wolters 1991, David \& Gillon 2002).

In the south of Brazil there is a good knowledge of the oniscidean fauna. The description of new species (Araujo \& Zardo 1995, Lopes \& Araujo 2003, Araujo \& Quadros 2005) as well as biogeographical surveys (LOPEs et al. 2005) and diversity inventories (Araujo et al. 1996, Almerão et al. 2006) have been conducted, revealing a considerable heterogeneity in species richness, diversity and composition (LOPEs et al. 2005).

As pointed by LeWINSOHN et al. (2005), invertebrate conservation depends on conserving entire habitats and on a more thorough understanding of their roles in maintaining ecosystem processes. Therefore, in the present study we provide an estimative of the participation of syntopic oniscideans in the soil processes, in addition to the description of an assemblage. Based on size and abundance, we have elected the two most representative species for a laboratory evaluation of feeding rates and the subsequent estimative of their contribution to litter processing in a subtropical forest of southern Brazil.

\section{MATERIAL AND METHODS}

\section{Sampling}

We selected a site of $216 \mathrm{~m}^{2}$ next to "Trilha da Onça" on a hill slope near the lagoon beach "Praia da Onça" $\left(30^{\circ} 34^{\prime} \mathrm{S}\right.$ $51^{\circ} 05^{\prime} \mathrm{W}$ ) in the Parque Estadual de Itapuã (PEI). The vegetation community is a secondary, semi-deciduous forest. For a more detailed description of the study site see Almerão et al. (2006) and Quadros \& Araujo (2007). The site of $216 \mathrm{~m}^{2}$ was divided in 12 consecutive sectors $\left(18 \mathrm{~m}^{2}\right)$. Monthly, from May 2004 to April 2005, we sorted and extracted one sample from each sector, totaling 144 samples in one year. Although previous studies used the hand-search method for the collection of animals, we chose to sample a known area, using a circular bottom-less recipient of $707 \mathrm{~cm}^{2}$. From the interior of this recipient, we transferred all vegetal material and the top soil layer ( $\approx 3 \mathrm{~cm}$ deep) to plastic bags to be hand-searched in the lab. This method allows the capture of the smallest individuals as well as the largest (see Araujo \& Bond-Buckup 2005, Quadros \& Araujo 2007), the disadvantage being the time-consuming task of examining all the contents.

\section{Assemblage description}

After the identification and counting of the individuals, the species were classified according to size and eco-morphological groups. Size classification followed BEGON et al. (2005): Mesofauna comprises animals with up to $2 \mathrm{~mm}$ body width, asnd Macrofauna comprises animals with $>2 \mathrm{~mm}$ and $<20$ $\mathrm{mm}$. The classification of terrestrial isopods into eco-morphological groups was according to SchmaLlfuss (1984).

An analysis of the variance/mean ratio for each species density suggested a clumped distribution for all species (variance $>$ mean). Species density was grouped in seasons, transformed $\left(\log _{10}+1\right)$ to minimize the effects of the clumped distribution (Araujo \& Bond-Buckup 2005) and compared with ANOVA. Average density of Atlantoscia floridana (van Name, 1940) and Balloniscus glaber Araujo \& Zardo, 1995 is published elsewhere (Quadros \& Araujo 2007).

Aggregation was quantified monthly through the Morisita's Index of Dispersion (MID) as follow: MID $=\left[\mathrm{n}\left(\Sigma \mathrm{i}^{2}-\right.\right.$ $\left.\left.\sum \mathrm{i}\right) /\left(\left(\sum \mathrm{i}\right)^{2}-\sum \mathrm{i}\right)\right]$, where $\mathrm{n}=12$ (number of samples per month) and $\mathrm{i}=$ number of individuals per sample (ElLIOT 1983). This index was chosen because it is independent of the number of individuals (ELLIOT 1983), which was highly variable in this study.

Association between pairs of species was calculated in two ways, both described in Southwood \& Henderson (2000). First we constructed presence-absence contingency tables for each pair of species. Then, the $\chi^{2}$ statistics is calculated for each pair: $\chi^{2}=\left[n[|a d-b c|-(n / 2)]^{2}\right] /[(a+c)(b+d)(a+b)(c+d)]$, where the letters $\mathrm{a}, \mathrm{b}, \mathrm{c}$ and $\mathrm{d}$ correspond to the number of samples with: both species (a); only species B (b); only species A (c) and none species (d). Deviation from random distribution was tested with Fisher's exact test, as recommended in cases where expected numbers are lower than five (Southwood \& Henderson 2000).

After identifying significant $\chi^{2}$, we calculated the coefficient of mean square contingency $\left(\mathrm{C}_{\mathrm{AB}}\right)$ to give a quantitative value for comparison with other species: $C_{A B}=\left[\operatorname{sqrt}\left(\chi^{2} /\left(n+\chi^{2}\right)\right)\right]$, where $C_{A B}=$ coefficient of association between species $A$ and $B$; $\mathrm{n}=$ total number of occurrences and $\chi^{2}$ as calculated above (Southwood \& HeNDERSON 2000).

The second index was the proportion of individuals occurring together $\left(\mathrm{I}_{\mathrm{AB}}\right): \mathrm{I}_{\mathrm{AB}}=2[(\mathrm{~J} /(\mathrm{A}+\mathrm{B}))-0.5]$, where $\mathrm{J}=$ number of individuals of $\mathrm{A}$ and $\mathrm{B}$ in samples where both species are present and $\mathrm{A}$ and $\mathrm{B}=$ total individuals of $\mathrm{A}$ and $\mathrm{B}$ in all samples (SOUTHWOOd \& Henderson 2000).

Also, intraspecific and interespecific aggregation were calculated as in Presa Авós et al. (2006). Intraspecific aggrega-

Revista Brasileira de Zoologia 25 (1): 58-66, March, 2008 
tion $\left(\mathrm{J}_{\mathrm{A}}\right)$ is given by $\mathrm{J}_{\mathrm{A}}=\left[\left(\mathrm{V}_{\mathrm{A}} / \mathrm{m}_{\mathrm{A}}^{2}\right)-\left(1 / \mathrm{m}_{\mathrm{A}}\right)\right]$, where $\mathrm{V}_{\mathrm{A}}=$ variance and $\mathrm{m}_{\mathrm{A}}=$ mean number of individuals of species A per sample. Interespecific aggregation $\left(\mathrm{L}_{A B}\right)$ is $\mathrm{L}_{\mathrm{AB}}=\left[\right.$ covariance ${ }_{A B} /\left(\mathrm{m}_{A} \mathrm{~m}_{B}\right)$, where $m_{A}$ and $m_{B}=$ mean number of species $A$ and $B$ per sample, respectively. A value of $\mathrm{L}_{\mathrm{AB}}>0$ indicates a positive association and $\mathrm{L}_{\mathrm{AB}}<0$ indicates a negative association (PRESA ABós et al. 2006). The relationship between these two measures was calculated as: $S_{A B}=\left|\left(J_{A}-1\right)\left(J_{B}-1\right)\right| /\left[\left(L_{A B}-1\right)^{2}\right]$. A value of $S_{A B}>1$ indicates that intraspecific aggregation is stronger then interespecific aggregation (PRESA ABÓs et al. 2006).

\section{Biomass and estimative of leaf litter processing}

Due to their abundance and size only $A$. floridana and $B$. glaber were chosen for biomass and litter processing estimates. We obtained their biomass by drying all specimens at $80^{\circ} \mathrm{C}$ for $48 \mathrm{~h}$ and weighing on an analytical balance (precision of $0.1 \mathrm{mg})$.

Collection of live animals occurred in June/July 2004. They were transported to the laboratory and maintained at ambient temperature $\left(\cong 18^{\circ} \mathrm{C}\right)$ and photoperiod (10:14 L:D) until experimentation. We also collected leaf litter to be offered as food during the experiments.

The experimental units consisted of small plastic boxes (8 cm diameter) containing cotton moistened with distilled water and $125 \pm 11 \mathrm{mg}$ of leaf litter (dry weight) as food. About 100 adult individuals of each species were distributed into the experimental units, totaling 50 units with two $B$. glaber individuals and 25 units with four $A$. floridana individuals. To control for autogenic changes in food weight, 20 units were set in the same conditions and maintained without the animals; the average percentage of weight lost in the controls was calculated and discounted from the amount consumed in each unit at the end of the experiment.

The units were checked daily for dead individuals and to provide water. Whenever occurred death, the unit was excluded from the analysis. The experiment was ended when approximately $50 \%$ of the food was consumed, which took from 7 to 14 days. Overall, 45 units of B. glaber and 14 units of A. floridana could be analyzed, this difference been due to mortality that occurred along the experiment. In the end, the animals, feces and the remaining leaf litter were separated in glass containers, oven dried and weighed and the rates calculated. Consumption rate (CR) and egestion rate (ER) were calculated on a dry weight basis, as mg food ingested per mg body weight per day and as mg feces produced per mg body weight per day, respectively. Assimilation efficiency (AE, \%) is the percentage assimilated from the amount consumed.

The estimative of the annual amount of leaf litter processed by A. floridana and B. glaber was obtained by multiplying the mean CR and ER by the mean biomass in the field, and compared to the annual litterfall budget of the studied environment, which was obtained from the literature. Otherwise stated, all values shown refer to mean $\pm 95 \%$ confidence intervals.

Revista Brasileira de Zoologia 25 (1): 58-66, March, 2008

\section{RESULTS}

After one year we obtained 3748 individuals of six species in five families (Tab. I). Balloniscus glaber, Atlantoscia floridana and Pseudodiploexochus tabularis (Giambiagi de Calabrese, 1939) (in order) were the commonest species, being present in ca. 80\% of total samples and representing 93\% of total individuals (Tab. I). Four of the six eco-morphological groups were present: a "runner", a "clinger", a "conglobating" and two "creepers" species (Tab. I). The group of Novamundoniscus gracilis Lopes \& Araujo, 2003 could not be determined, however we believe it is probably a "runner". In relation to size there was also a wide variation: from mesofaunal representatives of $2 \mathrm{~mm}$ as Alboscia itapuensis Araujo \& Quadros, 2005, to macrofaunal species of up to $13 \mathrm{~mm}$ in length, as B. glaber (Tab. I).

Trichorhina sp. could not be identified; it is probably a new species to science and probably the same referred by Lopes et al. (2005).

In average, each sample contained three species and $25 \pm 3$ individuals. Total number of individuals captured per month was in average $309 \pm 42$, corresponding to 368 ind $\mathrm{m}^{-2}$. The abundance of each species per month is shown in figure 1 . Alboscia itapuensis and $N$. gracilis were found mostly in winter and spring, in very low numbers: their densities were $1.3 \pm 0.7$ and $1 \pm 0.8$ ind $\mathrm{m}^{-2}$, respectively. The other four species were present through the year (Fig. 1). Density of Trichorhina sp. was also low, $22 \pm 8$ ind $\mathrm{m}^{-2}$, whereas the other three species were present in much higher densities: $96 \pm 21$ ind $\mathrm{m}^{-2}$ for $P$. tabularis, $113 \pm 22$ ind $\mathrm{m}^{-2}$ for A. floridana and $133 \pm 17$ ind $\mathrm{m}$ ${ }^{2}$ for $B$. glaber. Only A. floridana showed different densities between seasons (see Quadros \& Araujo 2007).

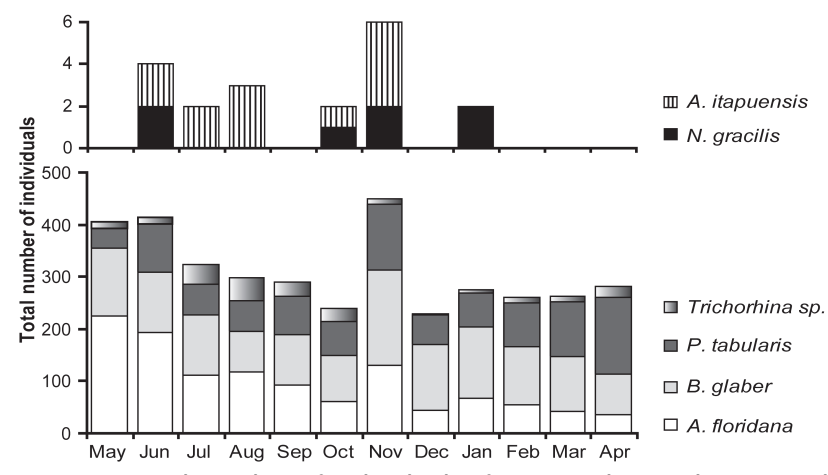

Figure 1. Total number of individuals of terrestrial isopods captured monthly at Parque Estadual de Itapuã, from May 2004 to April 2005.

As A. itapuensis and N. gracilis represented less than $1 \%$ of total individuals, they were excluded from dispersion and association analyses. All the others showed aggregated distribution (MID > 1), which varied in intensity along the year (Fig. 
Table I. Composition of the studied terrestrial isopod assemblage at Parque Estadual de Itapuã. (\% TN) percentage of total number of individuals captured, (\% TS) occurrence of the species in percentage of total samples. References are indicated by superscript numbers: 1) Araujo \& Zardo (1995), 2) Araujo et al. (1996), 3) Lopes \& Araujo (2003), 4) Taiti \& Ferrara (1979), 5) Ferrara \& Taiti (1981), 6) Lopes et al. (2001), 7) Araujo \& Quadros (2005), 8) Lopes et al. (2005).

\begin{tabular}{|c|c|c|c|c|c|}
\hline Taxa & $\% \mathrm{TN}$ & $\% \mathrm{TS}$ & Body length and size classification & $\begin{array}{c}\text { Eco-morphological } \\
\text { group }\end{array}$ & Known geographic distribution \\
\hline \multicolumn{6}{|l|}{ Macrofauna } \\
\hline \multicolumn{6}{|l|}{ Balloniscidae } \\
\hline Balloniscus glaber & 36.1 & 93.7 & $13.3 \mathrm{~mm}$ (male), $13.5 \mathrm{~mm}$ (female) ${ }^{1}$ & Clinger & Southern Brazil (RS) ${ }^{1}$ \\
\hline \multicolumn{6}{|l|}{ Philosciidae } \\
\hline Atlantoscia floridana & 31.2 & 83.3 & $5.2 \mathrm{~mm}$ (male), $7 \mathrm{~mm}$ (female) ${ }^{2}$ & Runner & South America ${ }^{2}$ \\
\hline \multicolumn{6}{|l|}{ Mesofauna } \\
\hline \multicolumn{6}{|l|}{ Dubioniscidae } \\
\hline Novamundoniscus gracilis & 0.3 & 4.2 & $3.6 \mathrm{~mm}$ (male), $4.2 \mathrm{~mm}$ (female) ${ }^{3}$ & Undetermined & Southern Brazil (RS) ${ }^{3}$ \\
\hline \multicolumn{6}{|l|}{ Armadillidae } \\
\hline Pseudodiploexochus tabularis & 26.1 & 71.5 & Diameter in conglobating ${ }^{4}=2 \mathrm{~mm}$ & Conglobating & $\begin{array}{l}\text { South Africa }{ }^{4} \text {; Ascension } \\
\text { Island }^{5} \text {; Southern Brazil (RS) }\end{array}$ \\
\hline \multicolumn{6}{|l|}{ Philosciidae } \\
\hline Alboscia itapuensis & 0.3 & 8.3 & $2 \mathrm{~mm}$ (male), $2.8 \mathrm{~mm}$ (female) ${ }^{7}$ & Creeper & Southern Brazil (RS) ${ }^{7}$ \\
\hline \multicolumn{6}{|l|}{ Platyarthridae } \\
\hline Trichorhina sp. & 6.0 & 39.0 & $3 \mathrm{~mm}$ & Creeper & $\begin{array}{l}\text { Unknown; probably Southern } \\
\text { Brazil (RS) }\end{array}$ \\
\hline
\end{tabular}

2). Trichorhina sp. showed the most intense aggregation, evidenced both by the MID and the intraspecific aggregation index (Tab. II). For both Trichorhina sp. and P. tabularis aggregation was stronger during winter and summer (Fig. 2). For $A$. floridana there was an increase in aggregation during the hottest months in summer. Balloniscus glaber showed no pronounced differences along the year (Fig. 2) and it had the lowest index of intraspecific aggregation (Tab. II).

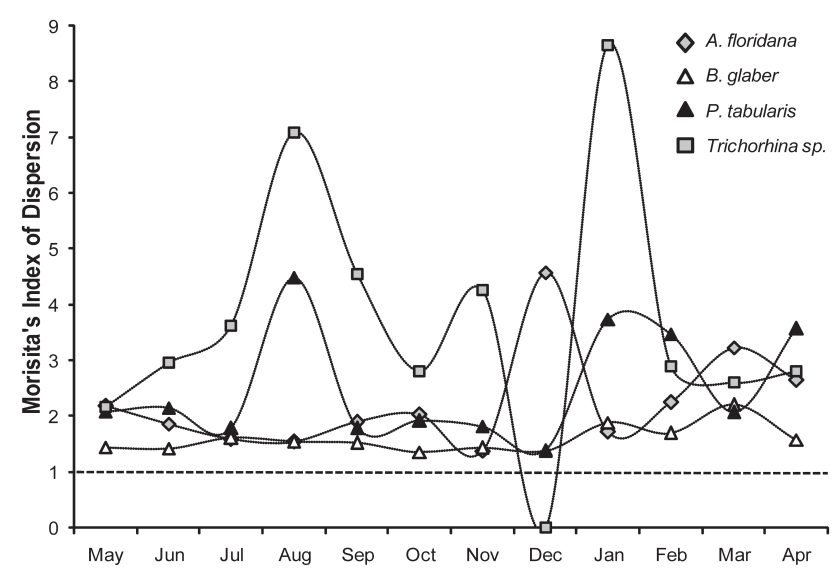

Figure 2. Isopod spatial distribution (Morisita's index of dispersion) in Parque Estadual de Itapuã, from May 2004 to April 2005. Values higher than 1 indicate an aggregate (contagious) distribution.
Atlantoscia floridana and B. glaber had the highest proportion of individuals occurring together (88\%) and a significant species association (Tab. III). Also, P. tabularis x B. glaber and $P$. tabularis $\mathrm{x}$ A. floridana species pairs shared a high proportion of individuals (Tab. III). Interespecific aggregation was higher for Trichorhina sp. x P. tabularis species pair; however, in all cases intraspecific aggregation was stronger than interespecific (Tab. II).

\section{Biomass}

With the exception of May and June 2004, biomass of $B$. glaber was higher than $A$. floridana (Fig. 3). The average biomass of A. floridana corresponded to $0.97 \mathrm{~kg} \mathrm{ha}^{-1}( \pm 0.2)$ and for $B$. glaber it was $4.9 \mathrm{~kg} \mathrm{ha}^{-1}( \pm 0.1)$. Considering the sum of the species, average biomass was $590 \mathrm{mg} \mathrm{m}^{-2}$, i.e. $5.90 \mathrm{~kg} \mathrm{ha}^{-1}( \pm 0.8)$. As can be seen in figure 3 , there was a significant difference between spring 2004 (Sep-Nov) and autumn 2005 (Mar-May) where total biomass was $6.9 \mathrm{~kg} \mathrm{ha}^{-1}( \pm 1.4)$ and $3.8 \mathrm{~kg} \mathrm{ha}^{-1}( \pm 1.6)$, respectively. Balloniscus glaber accounted for $87 \%$ of the total biomass. Total biomass of $A$. floridana and $B$. glaber, on a fresh weight (FW) basis, corresponded to $\approx 2560 \mathrm{mg} \mathrm{m}^{-2}$.

\section{Leaf litter processing}

Atlantoscia floridana presented higher CR and ER than B. glaber, the assimilation efficiency being the same for both species, about 30\% (Tab. IV). In table V we listed some annual litterfall estimative gathered from the literature. Considering only the leaf portion, we could expect an annual mean input of $5275 \mathrm{~kg} \mathrm{ha}^{-1}$ in deciduous and semi-deciduous forests of South and Southeast Brazil (Tab. V). By multiplying the feeding rates 
Table II. On the left, measure of intraspecific aggregation (J). On the right, measure of interespecific aggregation $\left(\mathrm{L}_{\mathrm{AB}}\right)$ in the upper triangle and the strength of intra- versus interespecific aggregation $\left(S_{A B}\right)$ in the bottom triangle.

\begin{tabular}{|c|c|c|c|c|c|c|c|}
\hline Species & J & Species & & B. glaber & A.floridana & Trichorhina sp. & P. tabularis \\
\hline & & & & \multicolumn{4}{|c|}{$\mathrm{L}_{A B}$} \\
\hline Trichorhina sp. & 5.00 & B. glaber & \multirow{4}{*}{$S_{A B}$} & & 0.25 & 0.220 & 0.28 \\
\hline P. tabularis & 1.75 & A.floridana & & 2.32 & & 0.001 & 0.02 \\
\hline A.floridana & 1.37 & Trichorhina sp. & & 6.19 & 14.15 & & 0.59 \\
\hline B. glaber & 0.54 & P. tabularis & & 2.59 & 6.32 & 6.550 & \\
\hline
\end{tabular}
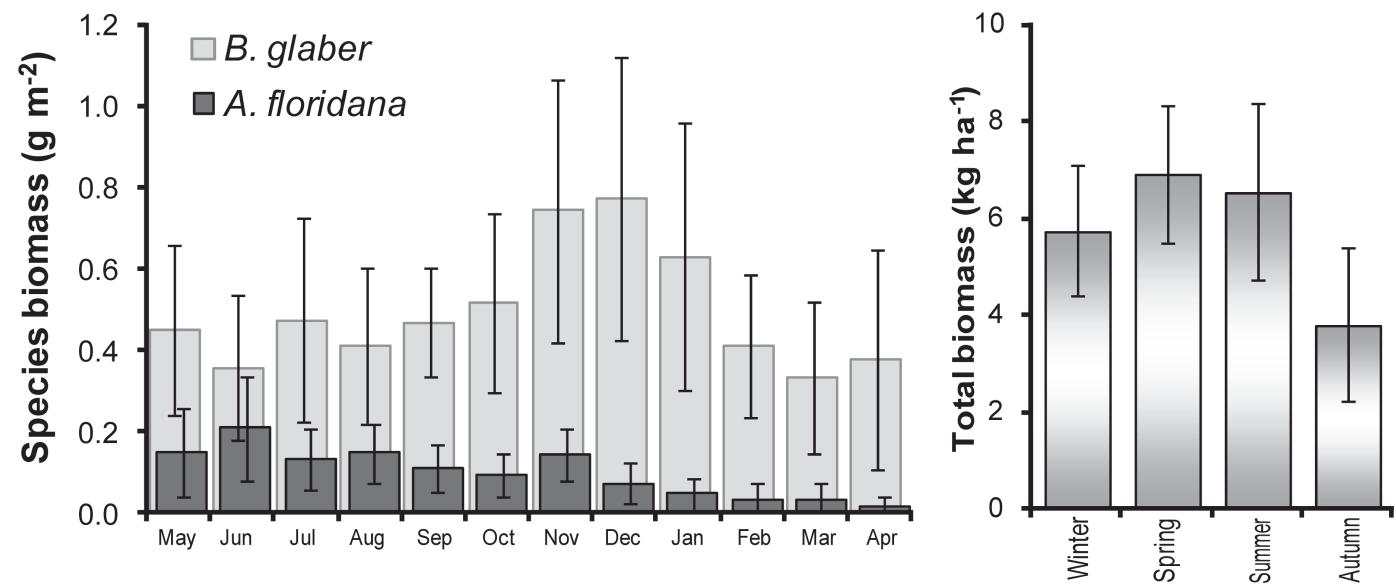

Figure 3. Biomass of A. floridana and B. glaber at Parque Estadual de Itapuã, between May 2004 and April 2005 (on the left) and the summed biomass of the two species per season (on the right). Values are mean $\pm 95 \%$ confidence intervals.

Table III. Measures of species association. In the upper triangle, values are the proportion of individuals occurring together $\left(\mathrm{I}_{\mathrm{AB}}\right)$ and in the bottom triangle there are the coefficient of association, through the mean square contingency $\left(C_{A B}\right)$. Both indexes range from -1 (absence of association) to +1 (complete association).

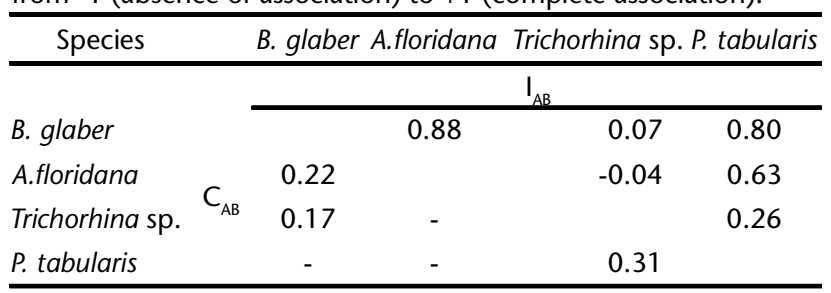

Table IV. Consumption and egestion rates and assimilation efficiency (\%) of Atlantoscia floridana and Balloniscus glaber feeding on mixed leaf litter from Parque Estadual de Itapuã. All rates refer to dry weight of samples. Values are mean $\pm 95 \%$ confidence intervals.

\begin{tabular}{lcc}
\hline \multicolumn{1}{c}{ Feeding rates } & A. floridana & B.glaber \\
\hline Consumption rate $\left(\mathrm{mg} \mathrm{mg}^{-1}\right.$ day $\left.^{-1}\right)$ & $0.70 \pm 0.18$ & $0.34 \pm 0.04$ \\
Egestion rate $\left(\mathrm{mg} \mathrm{mg}^{-1}\right.$ day $\left.^{-1}\right)$ & $0.48 \pm 0.15$ & $0.25 \pm 0.03$ \\
Assimilation efficiency $(\%)$ & $31.00 \pm 7.4$ & $27.00 \pm 3.50$ \\
\hline
\end{tabular}

and the average biomass obtained in the field, we estimate that the population of B. glaber could consume $610 \mathrm{~kg}$ of leaf litter per ha per year and $A$. floridana population could consume 250 $\mathrm{kg} \mathrm{ha}^{-1}$ year ${ }^{-1}$, totaling the processing of $860 \mathrm{~kg} \mathrm{ha}^{-1}$ year $^{-1}$, representing $16 \%$ of the annual input of leaves. From this amount, $620 \mathrm{~kg} \mathrm{ha}^{-1}$ year $^{-1}$ would return to the environment as feces.

\section{DISCUSSION}

The studied assemblage in PEI was characterized by a high diversity of morphological groups, a high proportion of endemic species and a high density and biomass along the year.

The species A. itapuensis and Trichorhina sp. presented the common characteristics of the endogean "creeper" species: unpigmented, small and narrow body. The "conglobating" species $P$. tabularis is probably endogean, as it was found in higher numbers within the fine soil layer. It is capable of rolling into a ball, when disturbed, and also to avoid desiccation. The "runner" A. floridana has the general morphology of most members of the family Philloscidae - a well pigmented, narrow body possessing long pereiopods adapted to run. Philosciids are common inhabitants of the leaf litter layer. Balloniscus glaber is a typical "clinger", as it possesses strong, short pereiopods adapted to grab the substrate, and if disturbed it pretends to be 
Table V. Annual litterfall (leaf portion only) of deciduous and semi-deciduous forests of South and Southeast regions of Brazil.

\begin{tabular}{lcl}
\hline \multicolumn{1}{c}{ Vegetal community and locality } & Annual litterfall kg ha year $^{-1}$ & Source \\
\hline Semi-deciduous (São Paulo, São Paulo) & 5900 & MEGURO et al. (1979) \\
Semi-deciduous (Jundiaí, São Paulo) & 5500 & MoreLLATO (1992) \\
Deciduous (Santa Maria, Rio Grande do Sul) & 5100 & CUNHA et al. (1993) \\
Semi-deciduous (Campinas, São Paulo) & 4500 & MARTINS \& RODRIGUES (1999) \\
Semi-deciduous (Ouro Preto, Minas Gerais) & 4000 & WERNECK et al. (2001) \\
Semi-deciduous (Ouro Preto, Minas Gerais) & 5300 & WERNECK et al. (2001) \\
Deciduous (Santa Maria, Rio Grande do Sul) & 6200 & KöNIG et al. (2002) \\
\hline
\end{tabular}

Average $5275 \mathrm{~kg} \mathrm{ha}^{-1}$ year $^{-1}$.

dead (thanatosis). It was found in the litter and buried in the upper soil layer. All these groups represent some of the various strategies employed by oniscideans to cope with the enemies and climatic challenges of the terrestrial life (Schmalfuss 1984).

For the coastal plains of Rio Grande do Sul, which includes the PEI area, Lopes et al. (2005) recorded seven oniscidean species. Five of them occur in the present assemblage: $P$. tabularis, B. glaber, A. floridana, N. gracilis, and Trichorhina sp. The other two are B. sellowii (Brandt, 1833) and Neotroponiscus daguerrii (Giambiagi de Calabrese, 1939), and the latter is known to occur in the PEI area (Almerão et al. 2006). Neotroponiscus daguerrii is commonly found under tree barks or in bromeliads (ARAujo et al. 1996), and therefore was out of our study range. Balloniscus sellowii is found near the beaches of PEI, often in abundance but it is not found in the interior of the hill forests.

The present assemblage showed a high number of endemism, which highlights the importance of the PEI area to the conservation of this invertebrate fauna in southern Brazil. Besides $P$. tabularis and A. floridana, the other four species are known to occur only in the Rio Grande do Sul state, and to the present A. itapuensis is recorded only for the PEI (Araujo \& Quadros 2005). Also, the populations of A. itapuensis and $N$. gracilis appear to be very small. We should note, however, that their densities could have been underestimated if their true microhabitat was outside the range of our collection method, and this deserves further attention. As the forest ground is the commonest environment studied, nothing is known, for example, about the ecology and biology of endogean and arboricolous oniscidean species.

As expected, the species in PEI were not homogenously distributed. Also, there was a relationship between body size and intraspecific aggregation. It was more intense for the smallest species and less intense for the largest species; moreover, along the year it was more intense during the hottest months. Aggregation can be due to the spatial heterogeneity of resources such as shelters (HASSALL \& TUCK 2007), mates and good quality food. Isopods are capable of orientate to good quality resources through hygro/tigmokinesis (EDNEY 1968) and olfaction, by which they perceive the aggregation pheromone present in the feces (TAKEDA 1984) and air-borne metabolites that indicate valuable food (Zimmer et al. 1996). Strong intraspecific aggregation may lead to increase interference competition, but it also facilitates coexistence (Presa Abós et al. 2005). The "aggregation model of coexistence" predicts coexistence between potentially competing species where intraspecific aggregation is stronger than interespecific (Presa Aвós et al. 2005), which was the case in all species pairs tested in the present study.

It seems that for the oniscideans in PEI, intraspecific aggregation is intense for all species, maybe due to spatial heterogeneity. It is possible that competition is avoided through: 1) abundance of resources, which permits high density/biomass of isopods and/or 2) morphological/ecological differences between species, which allows the exploitation of different resources, or even the same resources in different proportions.

Our results indicate that $A$. floridana and B. glaber are the most representative isopods species in the present assemblage, in terms of size (= biomass) and abundance. Their high association indicates similarity in resource use, despite being different in morphology. Also, in the lab they feed intensely on leaf detritus, confirming their detritivorous status. As they are easy to collect and distinguish from the other species, they constitute suitable species for laboratory experiments and were therefore chosen to be our models.

The biomass of the isopod species in PEI was higher than it would be expected for terrestrial isopods, which in forests it is generally below $2000 \mathrm{mg} \mathrm{FW} \mathrm{m}^{-2}$ (Tsukamoto 1977, Davis \& Sutton 1977, Hornung \& Warburg 1995, Gongalsky et al. 2005).

The consumption rates obtained for $B$. glaber and $A$. floridana were high, compared to other terrestrial isopods (ZIMMER et al. 2002, DiAS \& HASSALL 2005) and detritivorous invertebrates: Diplopods consume up to $51 \mathrm{mg} \mathrm{g}^{-1} \mathrm{~d}^{-1}$ (SzLÁveCz 1985, David \& GILLON 2002). Salt marsh amphipods consume from 7 to 424 $\mathrm{mg}^{-1} \mathrm{~g}^{-1}$ day AFDW, depending on the substrate (DiAs \& HaSsall 2005). KNollenberg et al. (1985) obtained a CR of $11 \mathrm{mg} \mathrm{g}^{-1} \mathrm{~d}^{-1}$ for Lumbricus terrestris and SzLÁveCz (1985) registered a CR of $29 \mathrm{mg}$ $\mathrm{g} \mathrm{FW}^{-1} \mathrm{~d}^{-1}$ for Fridericia ratzeli, both Oligochaeta species. However, the possibility that the rates presented here for A. floridana and $B$. glaber are over estimates cannot be excluded, as we offered mixed litter whereas usually a single species litter is offered as food. Detritivores as isopods and diplopods often show 
higher consumption rates when feeding on a mixed litter (Szlávecz \& Pobozsny 1985, Ashwini \& SRidhar 2005). Even though, in the context of the present study the use of mixed litter was more appropriated since it better fitted the natural conditions faced by A. floridana and B. glaber in the field. In the subtropical forests of Rio Grande do Sul, the absence of extremes of climate and the high vegetal diversity of the natural forests (CunHA 1993) allows a litter production along the entire year (CunHA 1993, KöNIG et al. 2002) and results in a forest floor with litter from several species and in different stages of decomposition.

The assimilation efficiency of $A$. floridana and B. glaber is within the range documented for other oniscideans (SomA \& SAITÔ 1983). The $\mathrm{AE}$ is influenced by the litter type (Dudgeon et al. 1990) and its decomposition state (Rushton \& Hassall 1983, Soma \& SAITO 1983) and varies widely between and within species, notwithstanding it is generally low (less than 30\%). This low AE is a product of a nutrient poor diet (decayed litter) which is compensated by increased consumption rates by soil detritivores (Dangerfield \& Milner 1996, Lawrence \& Samways 2003).

The amount of litter processed by oniscideans was so far estimated only for a few environments. Hassall \& SuTTON (1977) estimated that Armadillidium vulgare, Porcellio scaber and Philoscia muscorum consumed about $10 \%$ of the annual litterfall in grasslands. Dias \& SPRUNG (2003) suggested that Tylos ponticus could consume about $10 \%$ of the annual primary production of an abundant salt marsh plant. In other two studies, the participation of isopods was lower. MoCQUARD et al. (1987) estimated an annual consumption of $210 \mathrm{~kg} \mathrm{ha}^{-1}$ by Oniscus asellus and Philoscia muscorum, representing $7 \%$ of the annual litterfall and LAM et al. (1991) estimated a consumption of only $2.5 \%$ of the annual litterfall by four species.

Through high rates of consumption, low efficiency of assimilation and high field biomass, A. floridana and B. glaber are capable of producing a large amount of fecal pellets, contributing to the soil humus formation, which in turn supplies the forest growth (KNOEPP et al. 2000, Förster et al. 2006), as well as other saprophagous fauna. The estimative made in is this study expands the knowledge on isopod's contribution to litter processing and highlights their relevance to the soil conservation in the Neotropical forest studied.

\section{ACKNOWLEDGEMENTS}

We thank CAPES for the scholarship granted to AF Quadros; CNPq (Proc.73862/2004-2) and FAPERGS-PROAPP (Proc. 0409925) for the grants given to PB Araujo and SEMARS for support during the development of field work (Project SEMA-RS number 176).

\section{LITERATURE CITED}

Almerão, M.P.; M.S. Mendonça Jr; A.F. Quadros; E. Pedó; L.G.R Silva \& P.B. Araujo. 2006. Terrestrial isopod diversity in the subtropical Neotropics: Itapuã State Park, southern Brazil.
Iheringia, Série Zoologia 96 (4): 473-477.

Araujo, P.B. \& A.F. Quadros. 2005. A new species of Alboscia Schultz, 1995 (Crustacea: Isopoda: Oniscidea: Philosciidae) from Brazil. Zootaxa 1018: 55-60.

Araujo, P.B. \& C.M.L. Zardo. 1995. Uma nova espécie de Balloniscus Budde-Lund (Crustacea, Isopoda, Balloniscidae) do sul do Brasil. Revista Brasileira de Zooogia 12 (4): 785790.

Araujo, P.B. \& G. Bond-Buckup. 2005. Population structure and reproductive biology of Atlantoscia floridana (van Name, 1940) (Crustacea, Isopoda, Oniscidea) in southern Brazil. Acta Oecologica 28: 289-298.

Araujo, P.B.; L. Buckup \& G. Bond-Buckup. 1996. Isópodos terrestres (Crustacea, Oniscidea) de Santa Catarina e Rio Grande do Sul. Iheringia, Série Zoologia, 81: 111-138.

Ashwini K.M. \& K.R. SRIDHAR. 2005. Leaf litter preference and conversion by a saprophagous tropical pill millipede, Arthrosphaera magna Attems. Pedobiologia 49: 307-316.

Begon, M.; C.R Townsend \& J.L. Harper. 2005. Ecology: from individuals to ecosystems. Oxford, Blackwell Publishing, 752p.

Cunha, G.C.; L.A. Grendene; M.A. Durlo \& D.A. Bressan. 1993. Nutrient cycling in a seasonal deciduous forest with special respect to the mineral content produced by the litter fall. Ciência Florestal 3: 35-64.

Dangerfield, J.M. \& A.E. Milner. 1996. Millipede fecal pellet production in selected natural and managed habitats of southern Africa: implications for litter dynamics. Biotropica 28: 113-120.

DAVID, J.F. \& D. GILlon. 2002. Annual feeding rate of the millipede Glomeris marginata on holm oak (Quercus ilex) leaf litter under Mediterranean conditions. Pedobiologia 46: 42-52.

DAvis, R.C. \& S.L. SuTTON. 1977. A comparative study of changes in biomass of isopods inhabiting dune grassland. Scientific Proceedings of the Royal Dublin Society 6: 223-233.

Dias, N. \& M. Hassall. 2005. Food, feeding and growth rates of peracarid macro-decomposers in a Ria Formosa salt marsh, southern Portugal. Journal of Experimental Marine Biology and Ecology 325: 84-94.

Dias, N. \& M. Sprung. 2003. Population dynamics and production of the isopod Tylos ponticus in a Ria Formosa saltmarsh (South Portugal), p. 133-149. In: S. SFenthourakis; P.B. Araujo; E. Hornung; H. Schmalfuss; S. Taiti \& K. Szlavecz (Eds). The biology of terrestrial isopods. Crustaceana Monographs, 2. Leiden, Brill, 386p.

Dudgeon, D.; H.H.T. Ma \& P.K.S. Lam. 1990. Differential palatability of leaf litter to four sympatric isopods in a Hong Kong forest. Oecologia 84: 398-403.

EDney, E.B. 1968. Transition from water to land in isopod crustaceans. American Zooogist 8: 309-326.

ElLIot, J.M. 1983. Some methods for the statistical analysis of samples of benthic invertebrates. Kendal, Titus Wilson \& Son, 157p. 
Ferrara, F. \& F. Taiti. 1981. Terrestrial isopods from Ascension Island. Monitore Zoologico Italiano 14: 189-98.

Förster, B.; K. Muroya \& M. Garcia. 2006. Plant growth and microbial activity in a tropical soil amended with faecal pellets from millipedes and woodlice. Pedobiologia 50: 281-290.

Gongalsky, K.B.; F.A. SAvin; A.D. Pokarzhevski \& Z.V. Filimonova. 2005. Spatial distribution of isopods in an oak-beech forest. European Journal of Soil Biology 41: 117-122.

Hassall, M. \& J. Tuck. 2007. Sheltering behavior of terrestrial isopods in grasslands. Invertebrate Biology 126 (1): 46-56.

Hassall, M \& J.M. DANGERFIELD. 1989. Inter-specific competition and the relative abundance of grassland isopods. Monitore Zoologico Italiano 4: 379-397.

Hassall, M. \& S.L. Sutton. 1977. The role of isopods as decomposers in a dune grassland ecosystem. Scientific Proceedings of the Royal Dublin Society 6: 235-245.

Hassall, M. \& S.P. Rushton. 1982. The role of coprophagy in the feeding strategies of terrestrial isopods. Oecologia 53: 374381.

Hornung, E. \& M.R. Warburg. 1995. Seasonal changes in the distribution and abundance of isopods species in different habitats within the mediterranean region of northern Israel. Acta Oecologica 16: 431-445.

Hornung, E. \& M.R. WARBURg. 1996. Intra-habitat distribution of terrestrial isopods. European Journal of Soil Biology 32 (4): 179-185.

Judas, M. \& H. Hauser. 1998. Patterns of isopod distribution: From small to large scale. Israel Journal of Zoology 44: 333-343.

Knoepr, J.D.; D.C. Coleman; D.A. Jr. Crossley \& J.S Clark. 2000. Biological indices of soil quality: an ecosystem case study of their use. Forest Ecology and Management 138: 357368.

Knollenberg, W.G.; R.W. Merritt \& D.L. Lawson. 1985. Consumption of leaf litter by Lumbricus terrestris (Oligochaeta) on a Michigan woodland floodplain. American Midland Naturalist 113: 1-6.

KöNIG, F.G.; V. Schumacher; E.J. Brun \& I. Seling. 2002. Evaluation of the seasonal variation of litter production in a seasonal deciduous forest in Santa Maria, RS. Revista Árvore 26: 429435.

LAM, P.K.S.; D. Dudgeon \& H.H.T. Ma. 1991. Ecological energetics of populations of four sympatric isopods in a Hong Kong forest. Journal of Tropical Ecology 7: 475-490.

LaWrence, J.M. \& M.J. Samways. 2003. Litter breakdown by the Seychelles giant millipede and the conservation of soil processes on Cousine Island, Seychelles. Biological Conservation 113: 125-132.

Lewinsohn, T.M.; A.V.L. Freitas \& P.I. Prado. 2005. Conservation of Terrestrial Invertebrates and Their Habitats in Brazil. Conservation Biology 19: 640-645.

Lopes, E.R.C. \& P.B. Araujo. 2003. Nova espécie de Novamundoniscus Schultz (Isopoda, Oniscidea, Dubioniscidae) para o
Rio Grande do Sul, Brasil. Revista Brasileira de Zoologia 20 (4): 611-614.

Lopes, E.R.C.; P.B. Araujo \& G. Bond-Buckup. 2001. Pseudodiploexochus tabularis (Barnard), novo registro de Armadillidae (Crustacea, Isopoda, Oniscidae) para o Brasil. Revista Brasileira de Zoologia 18 (2): 655-656.

Lopes, E.R.C.; M.S. Mendonça Jr; G. Bond-Buckup \& P.B. Araujo. 2005. Oniscidea diversity across three environments in an altitudinal gradient in northeastern Rio Grande do Sul. European Journal of Soil Biology 41 (3-4): 99-108.

Lymberakis, P.; M. Moysis \& S. Sfenthourakis. 2003. Altitudinal variation of oniscidean communities on Cretan moutains, p. 217-230. In: S. Sfenthourakis; P.B. Araujo; E. Hornung; H. Schmalfuss; S. Taiti \& K. Szlavecz (Eds). The biology of terrestrial isopods. Leiden, Brill, Crustaceana Monographs 2, 386p.

Martins, S.V.; R.R. Rodrigues. 1999. Produção de serapilheira em clareiras de uma floresta estacional semidecidual no município de Campinas, SP. Revista Brasileira de Botânica 22: 405-412.

Matsumoto, T. \& T. Aве. 1979. The role of termites in an equatorial rain forest ecosystem of West Malaysia II. Leaf litter consumption on the forest floor. Oecologia 38: 261-274.

Meguro, M.; G.N. Vinueza \& W.B.C. Delitti. 1979. Cycling of mineral nutrients in a secondary semideciduous forest - São Paulo. I - Litter production and mineral content. Boletim Botânico da Universidade de São Paulo 7: 11-31.

Mocquard, J.P.; P. Juchault; P. Jambu \& E. Fustec, 1987. Essai d'évaluation du rôle des crustacés oniscoïdes dans la transformation des litières végétales dans une forêt de la France. Revue d'écologie et de Biologie du Sol 24: 311327.

Morellato, L.P.1992. Nutrient cycling in two south-east Brazilian forests. I. litterfall and litter standing crop. Journal of Tropical Ecology 8: 205-215.

Presa Abós, C.; F. Lepori; B.G. Mckie \& B. Malmqvist. 2006. Aggregation among resource patches can promote coexistence in stream-living shredders. Freshwater Biology 51: 545-553.

Quadros A.F. \& P.B. Araujo. 2007. Ecological traits of two neotropical oniscideans (Crustacea: Isopoda). Acta Zoologica Sinica 53 (2): 241-249.

Rushton, S.P. \& M. Hassall. 1983. Food and feeding rates of the terrestrial isopod Armadillidium vulgare (Latreille). Oecologia 57: 415-419.

Scheu, S. \& V. Wolters. 1991. Influence of fragmentation and bioturbation on the decomposition of 14C-labelled beech leaf litter. Soil Biology and Biochemistry 23: 1029-1034.

Schmalfuss, H. 1984. Eco-morphological strategies in terrestrial isopods. Symposia of the Zoological Society of London 53: 339-368.

Schmalfuss, H. 2003. World catalog of terrestrial isopods (Isopoda, Oniscidea). Stuttgarter Beiträge zur Naturkunde A 654: 1- 
341. Available in the World Wide Web at: http:// www.naturkundemuseum-bw.de/stuttgart/projekte/ oniscidea-catalog/Cat_terr_isop.pdf [Accessed in 20/VI/2007].

Soma, K. \& T. SAITô. 1983. Ecological studies of soil organisms with reference to the decomposition of pine needles. II. Litter feeding and breakdown by the woodlouse Porcellio scaber. Plant and Soil 75: 139-151.

Southwood, T.R.E. \& P.A. Henderson. 2000. Ecological methods. Oxford, Blackwell Science, 575p.

Szlávecz, K. 1985. The effects of microhabitats on the leaf litter decomposition and on the distribution of soil animals. Holartic Ecology 8: 33-38.

Szlávecz, K. \& M. Pobozsny. 1995. Coprophagy in isopods and diplopods: a case for indirect interaction. Acta Zoologica Fennica 196: 124-128.

TAiti, S. \& F. Ferrara. 1979. Il genere Pseudodiploexochus Arcangeli, 1934 (Armadillidae, Oniscoidea, Isopoda). Revue de Zoologie Africaine 93 (1): 151-184.

TAKEDA, N. 1984. The aggregation phenomenon in terrestrial isopods. Symposia of the Zoological Society of London 53: 381-404.

Tsukamoto, J. 1977. Soil macro-animals on a slope in a deciduous broad-leave forest. I. Two species of terrestrial isopoda: Ligidium japonicum and L. paulum. Japanese Journal of Ecology 26: 201-206.

Received in 19.VII.2007; accepted in 04.III.2008.
Weвв, D.P. 1977. Regulation of Deciduous Forest Litter Decomposition by Soil Arthropod Feces. In: W.J. MatTson (Ed.). The role of arthropods in forest ecosystems. New York, Springer-Verlag, 104p.

Werneck, M.S.; G. Pedralli \& L.F. Gieseke. 2001. Produção de serapilheira em três trechos de uma floresta semidecídua com diferentes graus de perturbação na Estação Ecológica do Tripuí, Ouro Preto, MG. Revista Brasileira de Botânica 24: 195-198.

Zimmer, M. 2002. Nutrition in terrestrial isopods (Isopoda: Oniscidea): an evolutionary-ecological approach. Biological Reviews 77: 455-493.

Zimmer, M. 2003. Habitat and resource use by terrestrial isopods (Isopoda, Oniscidea), p. 243-261. In: S. Sfenthourakis; P.B. Araujo; E. Hornung; H. Schmalfuss; S. Taiti \& K. Szlavecz. (Eds). The biology of terrestrial isopods. Leiden, Brill, Crustaceana Monographs 2, 386p.

Zimmer, M.; G. KaUTz \& W. Topp. 1996. Olfaction in terrestrial isopods (Isopoda: Oniscidea): responses of Porcellio scaber to the odour of litter. European Journal of Soil Biology 32: 141-147.

Zimmer, M.; S.C. Pennings; T.L. Buck \& T.H. Carefoot. 2002. Species-specific patterns of litter processing by terrestrial isopods (Isopoda: Oniscidea) in high intertidal salt marshes and coastal forests. Functional Ecology 16: 596-607. 